Vol. 8, No. 1, 2021

https://doi.org/10.23939/eem2021.01.020

UDC 330.33.012

JEL Classification Code: E32

S. Lykholat
Lviv Polytechnic National University, Ukraine, PhD, Associate Professor
E-mail: s1925p@i.ua
ORCID ID: 0000-0002-0517-6852

Y. Krykavskyi

Lviv Polytechnic National University, Ukraine, Doctor, Professor

E-mail: yevhenkrykavskyy@gmail.com,

ORCID ID: 0000-0002-1847-586x

V. Lozynskiy

Lviv Polytechnic National University, Ukraine, PhD, Senior teacher

E-mail: vasyl.t.lozynskiy@1pnu.ua

ORCID ID: 0000-0001-5778-9514

Dnipro university of technology candidate of economic sciences, Ukraine,

$\mathrm{PhD}$, Associate Professor

E-mail: shynkarenko.n.v@nmu.one

ORCID ID: 0000-0001-7519-336x

\title{
DETERMINATION OF THE INFLUENCE OF THE ECONOMIC CYCLE STAGES ON THE INNOVATIVE POTENTIAL OF SMALL ENTREPRENEURSHIP
}

\begin{abstract}
Annotation. The small business sector is studied. It is hypothesized that the small business sector has a significant innovative potential, the possibilities of which depend on the economic cycle of market conjuncture. It has been hypothesized that innovation investment in the small business sector depends significantly on economic cycles, and that the structure / directions of innovation investment are determined by the global market conjuncture.

This is done in order to interpret the systemic / unsystematic development of small business in the context of public policy on the basis of appropriate calculations and the obtained results, as well as provides an understanding of the possibilities of realizing the innovative potential of small business. The peculiarity of this study is its complementarity "innovative potential of small business - technology transfer - economic cycles".
\end{abstract}

It has been established that investment in innovation and technology transfer in the small business sector depend on market conjuncture and stages of the economic cycle that occur in a certain period (growth or recession). The identification of economic cycles allowed to form the directions of state regulation and reveal the possible risks associated with finding the innovative potential of small business.

The conducted research creates a basis for the implementation of the cluster policy program; contributes to the formation of appropriate tools for creating clusters; reveals favorable periods of labor involvement in the realization of innovation potential; helps to identify the periods of economic cycles in which it is appropriate to invest in their own self-education and modern technology. This approach will help increase the level of balance of the small business system on an innovative basis. 
Key words: innovation potential, small business, transfer of technological solutions, investment of innovations, economic cycles, information systems.

\section{Formulation of the problem}

Small business is a type of activity that plays an important role in the socio-economic development of any other country. Its development demonstrates the entrepreneurs' abilities to adapt to the rapidly changing economic environment.

In the modern realities effective entrepreneurial activity is possible only under certain socioeconomic conditions that will encourage citizens to conduct it. That is why the state should consider small business as a basis for social restructuring of society, which will be aimed at a socially oriented market economy. However, the state's insufficient attention to the creation of a favourable environment for the development of small business reduces the opportunities for the implementation of this type of activity at the level that is peculiar for economically developed countries.

The innovative potential of technologies is the possibility and prospects of investing innovations in the field of technology to strengthen the enterprise economic system. The potential for innovation by the small business is an indicator of the ability and readiness for the society transformation. Entrepreneur must not only have opportunities for improvement, but also be able to identify conditions as opportunities for innovation, be ready for their implementation. Despite the various components of the innovation potential of the small business, such as market, personnel, intellectual, technical and technological, it is necessary to single out information that reflects the degree of completeness and accuracy of information needed to make effective innovative decisions.

Thus, the peculiarity of this study will be the disclosure of complementarity "innovative potential of small business - technology transfer - economic cycles".

Purpose of the article is to identify the impact of the economic cycle of market conjuncture of the small business sector on its innovation potential, which will help solve such problems:

- to identify the main trends in the development of the small business sector to determine the relationship between the structure / directions of investment innovations and the global market conjuncture;

- to determine the significance of the impact of the stages of the economic cycle on the investment of innovations in the small business sector;

- to identify whether the small business sector has significant innovation potential, the size of which and the possibilities of using depend on the economic cycle of market conjuncture.

\section{Analysis of recent research}

In order to identify the parameters of the economic cycle of the small business system and assess the nature of its development, it is necessary to consider cyclicality as a form of economic activity from one cycle to another. As [1] noted, cyclicality is a form of evolution of economic activity. The source [1] states that cyclicity is a form of evolution of economic activity (activity).

Researching the opinions of scientists, we can argue about the genesis of cyclical activity, in which the law of the market prevails and each product creates it for itself and requires the involvement of appropriate resources to avoid economic imbalances. Cyclic activity is unstable and, according to [2] can both intensify and become depressed. [3-5]. Cyclic activity is unstable and may become more active or depressed [2]. Cyclical fluctuations occur in moments of economic crisis with a certain regularity [3] and cause a corresponding reaction of entrepreneurs, which depends on their experience, education, availability of innovative technologies and the reliability of the information obtained $[4,5]$. The ability of entrepreneurs to make non-standard (risky) management decisions within the limits allowed by law is also important [6]. Risk management is based on management theory and practical experience of the manager as a single logical and intersectoral chain, which aims at the process of personnel management in relation to economic cycles [7, 8]. Namely, education and experience of staff contribute to reducing risks in the process of economic cycles [9].

In the state [10] noted, that problems of small business formation are connected with political and 


\section{S. Lykholat, Y. Krykavskyi, V. Lozynskiy, N. Shynkarenko}

legal regulation from the philosophical standpoint of postpositivism. Whereas in the article [11] are considered as a model that is based on economic analysis of political behavior. Scientists argue that political decisions are not always altruistic or ideological, and as a result, those who are less protected suffer more. Therefore, we can talk about the lack of protection of small businesses in relation to big ones.

The reason for such insecurity may be objective difficulties. Thus, in times of financial and economic crises, political and legal regulation should be aimed at making anti-crisis decisions to implement the mechanisms of antidepressant economic policy; however, they are adopted, as a rule, late [12]. In [13], the authors expand such research because the financial crisis poses not only threats but also new opportunities for the development of small businesses in the Czech Republic and Slovakia. Other authors [14] deepen this statement by emphasizing that new technologies and their improvements bring not only a wide range of opportunities but also threats. That is, in different countries there are not only similar problems of business development but also there is a problem of implementation of experience in the conditions of economic dissonance.

Economic dissonance is particularly perceptible in times of crisis and has diametrically opposite consequences (eg, unstable economic business environment, inefficient business decisions) to those that would be expected in a different economic context [15]. This statement is supported by other scientists [16] and deepened by corporate social responsibility, which also depends on economic cycles and is most noticeable at a time of rising unemployment, inflation, decline investment activity. The authors note that small businesses are particularly dependent on economic cycles due to the fact that their activities often do not have a system for building cooperation with stakeholders. In the article [17] the author also describes the factors that can have consequences for entrepreneurs and emphasizes the structure of the economy and human capital, drawing attention to their role in the economic development of the state. Therefore, small business is becoming increasingly important in the economic development of the state [18] and, as noted in the article [19] they can be considered the main engine of economic growth because contribute to employment and changes in GDP (gross domestic product) by creating an intense competitive environment that requires strategic planning in a turbulent economic environment [20].

Researchers did not ignore the issue of financing economic activities taking into account economic cycles. [21] and [22] In the other researches $[21,22]$ the scientists reveal the impact of credit risk and its relationship with different groups of entrepreneurs depending on their size, period of existence and offer the development of internal rating systems with significant equity savings. Whereas other researchers [23, 24] consider the critical problem of entrepreneurial financing is the lack of long-term policy planning tools.

The changes that occur at the peak of economic cycles as potential benefits for achieving economic balance through the creation of nonstandard strategies and values with significant benefits for both small businesses and society [25]. An option to overcome the relevant difficulties may be the realization of innovation potential, which is expressed by the degree of implementation of innovative projects [26]. This approach is used in articles [27, 28]. The authors argue that the transfer of technologies and their commercialization, as well as the cooperation of business representatives with scientists and representatives of big business play a special role in the realization of the potential of small business representatives.

\section{Methodology of research}

The bibliographic method was used for the analysis of literary sources. The application of analysis and synthesis of actual material, the combination of induction and deduction in the study of deep processes of the domestic business system formed the basis for identifying the problem 
of reducing business activity. The index method was used in the calculation of base indices. The use of empirical methods, such as measurement, comparison and description allowed identifying empirical rules of structural change in the field of entrepreneurship. Regression analysis, cluster analysis and graphical method were used for situational analysis. The graphical method is used to visualize the levels of operational and economic activities of enterprises.

\section{The main results of the research}

Applying method of analysis and synthesis, monographic method, index method, economicmathematical modelling, cluster and regression analysis, graphical method will create an opportunity achieving the purpose of the article. The identification of the economic cycle stages of small business development will based on the results of cluster analysis using the statistical package SPSS 21.0 (USA).

In the process of this research, we will understand whether small businesses are able to respond to changes quickly in the external environment in conditions of limited access to financial resources, as well as determine the systemic/non-systematic development of small business. Identifying the presence of entropy will further generate recommendations for small business development. The parameters for identifying the economic cycle and assessing the systematic development of small business are the profitability of operating activities, the number of business entities, the number of employees, the volume of sales for 2010-2018.

Identifying the presence of entropy will further generate recommendations for small business development.

The activity of small business is based on scientific principles of interaction between the state and the market at the micro level, where the determinants of market organization of small business include freedom of action, possible risks, innovation and market efficiency to make a profit and meet entrepreneur's social and personal needs. While the determinants of public economic management includes economic orderliness, stability of decisions, social justice and economic growth.

It should be noted that the development of small business is influenced by a number of factors arising from the negative dynamics of key macroeconomic indicators. For example, a decline in GDP caused the reduction of working capital of small businesses. While due to the reduction of real incomes of the population there was a sharp decline in their purchasing power and a change in purchasing behavior, the period of use of purchased goods became longer, there was a reduction in domestic demand, etc. Under such conditions, large market players apply marketing measures, such as seasonal discounts, and, as a result, become monopolists of certain market segments. Such actions do not only have negative consequences for small businesses but also negatively affect their investment activity. The investment activity itself can be intensified by obtaining loans, however, limited access of small businesses to loan sources due to high lending rates, which are 24-36\% annually, cause a crisis of liquidity and defaults.

Despite the growing trend in the development of the small business sector, i.e. the number of newly registered entities, the level of profitability of operating and economic activities of these enterprises indicates the presence of a mediumterm economic cycle covering the period from 2010 to 2018 (Fig. 1, 2).

All four types of enterprises showed a minimum level of operating activity in 2014 (entities of microbusiness - $-30.1 \%$; small --7.9 ; medium-sized - -3.6; big - 0.7) and reached a maximum in 2017 medium-sized -7.3; big -11.2) and 2018 (microenterprises $-4.7 \%$; small -8.3) during the research period.

Two types of enterprises showed a minimum level of profitability of economic activity in 2014 (micro-entrepreneurs $--40.2 \%$; small --26.5 ) and reached a maximum in 2018 (micro-enterprises $-1.8 \%$; small -2.7 ) during the study period. The highest inflation index change was in $2014-23.9$, the lowest level of real wage growth was in $2015-79.8$. 


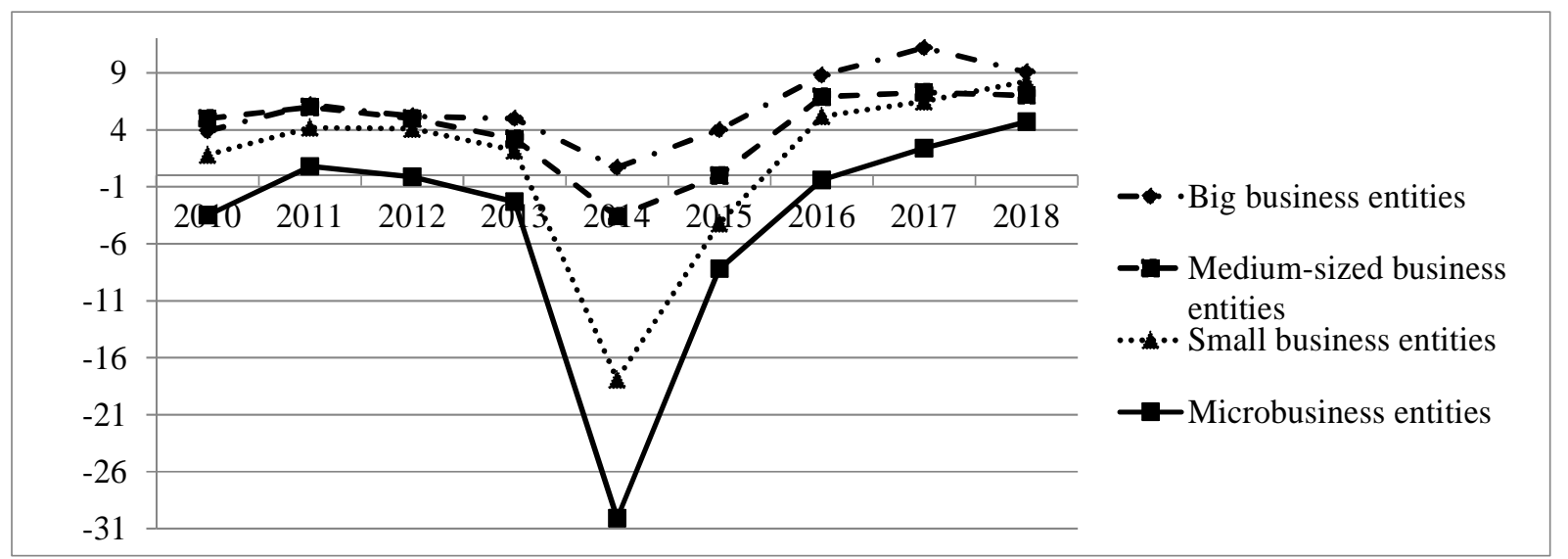

Fig. 1. The profitability level of operating activities of economic entities, \%

Note: own research based on the materials of the State Statistics Service of Ukraine

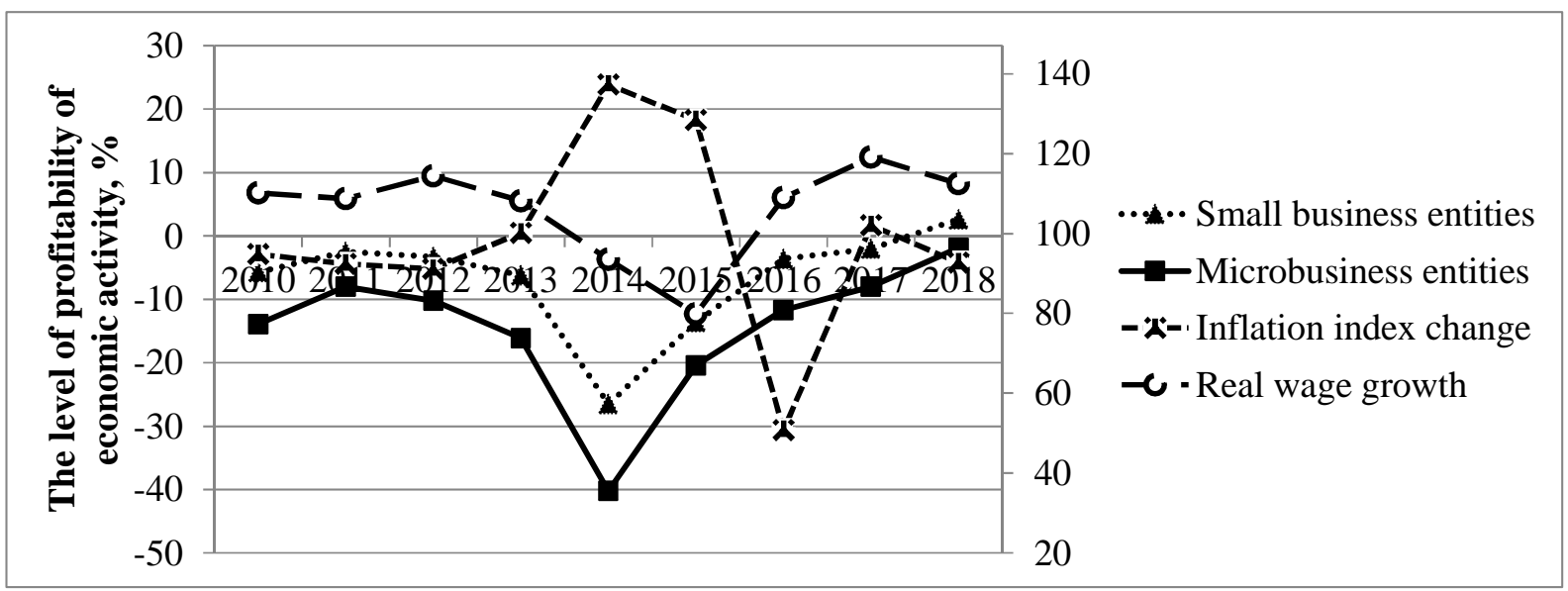

Fig. 2. The level of profitability of economic activity, \%

Note: own research based on the materials of the State Statistics Service of Ukraine

Researching economic cycles that slow down or accelerate economic development, scientists have put forward various ideas about the nature of their origin, which has a history of more than 200 years and is associated with the first industrial crisis in England (1825), USA (1836 and 1841), in France and Germany (1847). Scientists have put forward various ideas about the nature of their origin.

Some scientists considered economic cycles due to three levels with different durations (55 years, 10 years, 3 years, 4 months), which depend on technological innovation and institutional changes. That is they are a process creative destruction [29].
Therefore, the movement that occurs in the process of change is cyclical and involves recovery, recession, depression, recovery [30]. At the same time, there is an opinion that economic cycles are introduction (technological time), aggressive investment (financial time), synergy (production time), maturity (self-satisfaction time) [31]. Or uses the division: expansion, boom, recession, depression. As we see, scientists have different approaches to economic cycles, but everyone recognizes them. However, insufficient research has been conducted on the impact of economic cycles on small business development [32].

Typically, the economic cycle is divided into five stages or phases. The economy reaches the first phase shortly before the economic problems 
begin and the growth curve has a downward trajectory. For all four groups of enterprises and individual person-entrepreneurs, this phase covered the years 2010-2011.

The second stage is a decline in the activity of economic entities, characterized by a decrease in real household incomes, loss of public confidence in the banking sector, an increase in the number of enterprises with liquidity problems and financial stability. In the research, the second stage covered 2011-2013. Chain indices of some indicators of economic entities in the table 1 indicate that the second phase primarily affected big and medium-sized enterprises. It has led to a reduction in their economic activity while increasing the number of small enterprises characterized by greater mobility and flexibility in conditions of unstable market conjuncture.

Table 1

Chain indices of some economic entities indicators *

\begin{tabular}{|c|c|c|c|c|c|}
\hline Amount & Years & $\begin{array}{c}\text { big business } \\
\text { entities }\end{array}$ & $\begin{array}{c}\text { medium-sized } \\
\text { business entities }\end{array}$ & $\begin{array}{l}\text { small business } \\
\text { entities }\end{array}$ & $\begin{array}{c}\text { microbusiness } \\
\text { share }\end{array}$ \\
\hline \multirow{9}{*}{$\begin{array}{c}\text { Enterprises and } \\
\text { individual persons- } \\
\text { entrepreneurs }\end{array}$} & 2010 & $\mathrm{x}$ & $\mathrm{x}$ & $\mathrm{x}$ & $\mathrm{x}$ \\
\hline & 2011 & 1.125 & 0.987 & 0.777 & 0.768 \\
\hline & 2012 & 1.059 & 0.976 & 0.940 & 0.939 \\
\hline & 2013 & 0.944 & 0.935 & 1.078 & 1.084 \\
\hline & 2014 & 0.754 & 0.865 & 1.125 & 1.136 \\
\hline & 2015 & 0.851 & 0.933 & 1.023 & 1.027 \\
\hline & 2016 & 0.905 & 0.974 & 0.945 & 0.942 \\
\hline & 2017 & 1.042 & 1.009 & 0.967 & 0.965 \\
\hline & 2018 & 1.118 & 1.080 & 1.019 & 1.016 \\
\hline \multirow{9}{*}{$\begin{array}{c}\text { Employees in } \\
\text { enterprises and } \\
\text { individual persons- } \\
\text { entrepreneurs } \\
\text { (thousand people) }\end{array}$} & 2010 & $\mathrm{x}$ & $\mathrm{x}$ & $\mathrm{x}$ & $\mathrm{x}$ \\
\hline & 2011 & 1.020 & 0.959 & 0.896 & 0.856 \\
\hline & 2012 & 1.014 & 0.974 & 0.965 & 0.941 \\
\hline & 2013 & 0.960 & 0.958 & 1.001 & 1.022 \\
\hline & 2014 & 0.803 & 0.906 & 0.959 & 1.021 \\
\hline & 2015 & 0.892 & 0.952 & 0.933 & 0.967 \\
\hline & 2016 & 0.929 & 1.007 & 1.009 & 0.978 \\
\hline & 2017 & 0.984 & 0.990 & 1.022 & 1.021 \\
\hline & 2018 & 1.009 & 1.061 & 1.055 & 1.055 \\
\hline \multirow{9}{*}{$\begin{array}{l}\text { Employees in } \\
\text { enterprises and } \\
\text { individual persons- } \\
\text { entrepreneurs by } \\
\text { their size and type of } \\
\text { economic activity }\end{array}$} & 2010 & $\mathrm{x}$ & $\mathrm{X}$ & $\mathrm{x}$ & $\mathrm{x}$ \\
\hline & 2011 & 1.020 & 0.959 & 1.001 & 1.005 \\
\hline & 2012 & 1.014 & 0.973 & 0.972 & 0.934 \\
\hline & 2013 & 0.960 & 0.958 & 0.964 & 0.975 \\
\hline & 2014 & 0.803 & 0.906 & 0.851 & 0.846 \\
\hline & 2015 & 0.892 & 0.952 & 0.867 & 0.884 \\
\hline & 2016 & 0.929 & 1.007 & 1.061 & 1.031 \\
\hline & 2017 & 0.984 & 0.990 & 1.075 & 1.120 \\
\hline & 2018 & 1.009 & 1.061 & 1.088 & 1.115 \\
\hline
\end{tabular}

* Note: own calculations based on the materials of the State Statistics Service of Ukraine

The analysis of three indicators (number of enterprises; number of employees and hired workers) of chain indices shows the presence of feedback between big and medium-sized enterprises on the one hand and small ones on the other. Medium-sized and small enterprises responded 


\section{S. Lykholat, Y. Krykavskyi, V. Lozynskiy, N. Shynkarenko}

to the deteriorating economic conditions of doing business in 2011, and big ones - since 2013.

As for small enterprises, during this period most citizens were registered as individual personsentrepreneurs without hiring employees. Instead, the Cabinet of Ministers of Ukraine during this period did not take effective decisions to simplify the registration procedure and taxation for small enterprises and individual persons-entrepreneurs.

The World Bank's Rating Doing Business [33] assesses the business climate through the prism of indices of such business parts as starting a business, working with building permits, property registration, investor protection, taxes and other. According to the Rating, for an example, Ukraine in 2012 year took $152^{\text {nd }}$ place out of 183 . However, in 2019 this figure was $71^{\text {st }}$ among 190 countries. This change became possible due to significant changes in such categories as "international trade" and "fulfilment of contractual commitments" as a result of relevant government decisions.

The third phase is the "lowest drop point". Without a doubt, we can say that Ukraine's economy performed the worst in 2014. The range of reasons, taking into account military, political, economic, social, demographic factors, is quite wide, but their consideration and analysis are not the subject of this article.

The fourth phase occurs when the contraction of the economy stops and the trajectory takes an upward direction. For the studied groups of enterprises and individual persons-entrepreneurs, this phase covered the years of 2015-2016. This is evidenced by the profitability of operating activities, chain indices of the number of entities, and employees.

The fifth stage is the "phase of economic recovery" (2017-2018). Operating index exceeds the previous maximum (in 2011) in all four groups of entities. The increase and expansion of production lead to an increase in the purchase of raw materials and hiring additional workers. One of the options for models of economic system development is the implementation of cluster policy. Depending on the development goals, there are four variants of cluster policy models that are formed at different levels of the economy, namely the model of national preferences, regional development, support for small and medium-sized businesses, establishing links between science and industry [34]. Significant domestic intellectual potential generates interest in the last two models mentioned above. The implementation of these models is aimed at creating a system of institutions that manage knowledge transfer, establishing links between science, industry, finance, services sector, public organizations, etc. To support small and medium-sized businesses, the main measures are to strengthen the interaction between knowledge sources for studying and compensation for the lack of innovative opportunities. The creation of a "critical mass" in emerging technologies, through the involvement of scientific potential, investors, and enterprises are characteristics of the fourth model.

The results of cluster analysis with the help of software statistical package SPSS 21.0 (USA). Two variables were used to build the cluster model: the number of employees in enterprises and at individual persons-entrepreneurs (thousands of people) and their volume of sold products (goods, services) (million UAH).

The Chebyshev distance was chosen as the method of determining the distances between the clusters, because the studied observations are "different" largely by one indicator, namely the volume of sold products (Table 2).

Within the cluster analysis, the Chebyshev distance was used to determine the distance between the objects of the population, which is calculated as the maximum difference modulus of the components of numerical vectors formula (1).

$$
l_{\infty}(x, y)=\max _{i=1, \ldots n}\left|x_{i}-y_{i}\right| .
$$

The application of Ward's method involves the use of analysis of variance to estimate the distances between clusters, when the sum of squares (SS) is minimized for two hypothetical clusters that can be formed at each step of the clustering process. This method is considered effective and forms small clusters, which correlates with the subject of our study and the time interval that is analyzed. 
Determination of the influence of the economic cycle stages...

Table 2

\section{Proximity matrix}

\begin{tabular}{|l|l|l|l|l|l|l|l|l|l|}
\hline \multirow{2}{*}{ Years } & \multicolumn{9}{|c|}{ The Chebyshev distance } \\
\cline { 2 - 11 } & 2010 & 2011 & 2012 & 2013 & 2014 & 2015 & 2016 & 2017 & 2018 \\
\hline 2010 & 0.000 & 1.497 & 1.951 & 1.933 & 2.443 & 3.244 & 3.149 & 2.904 & 2.788 \\
\hline 2011 & 1.497 & 0.000 & 0.454 & 0.437 & 0.947 & 1.748 & 1.652 & 2.045 & 2.742 \\
\hline 2012 & 1.951 & 0.454 & 0.000 & 0.028 & 0.492 & 1.294 & 1.198 & 1.869 & 2.566 \\
\hline 2013 & 1.933 & 0.437 & 0.028 & 0.000 & 0.510 & 1.311 & 1.215 & 1.841 & 2.538 \\
\hline 2014 & 2.443 & 0.947 & 0.492 & 0.510 & 0.000 & 0.801 & 1.089 & 1.764 & 2.460 \\
\hline 2015 & 3.244 & 1.748 & 1.294 & 1.311 & 0.801 & 0.000 & 0.541 & 1.216 & 1.912 \\
\hline 2016 & 3.149 & 1.652 & 1.198 & 1.215 & 1.089 & 0.541 & 0.000 & 0.675 & 1.372 \\
\hline 2017 & 2.904 & 2.045 & 1.869 & 1.841 & 1.764 & 1.216 & 0.675 & 0.000 & 0.697 \\
\hline 2018 & 2.788 & 2.742 & 2.566 & 2.538 & 2.4600 & 1.912 & 1.372 & 0.697 & 0.000 \\
\hline
\end{tabular}

Note: own calculations

The proximity matrix allows identifying the similarity (according to certain variables) of such observation periods as 2011-2013, 2015-2016 and 2017-2018. The analysis of the Chebyshev distance in terms of sales volume and number of employees confirms the previously conclusion made that the economic downturn in 2014 was a logical result of the business sector development over the past three years.

Since the number of observations is not significant, the hierarchical Ward's clustering method was used (Fig. 3), which generated identical results.

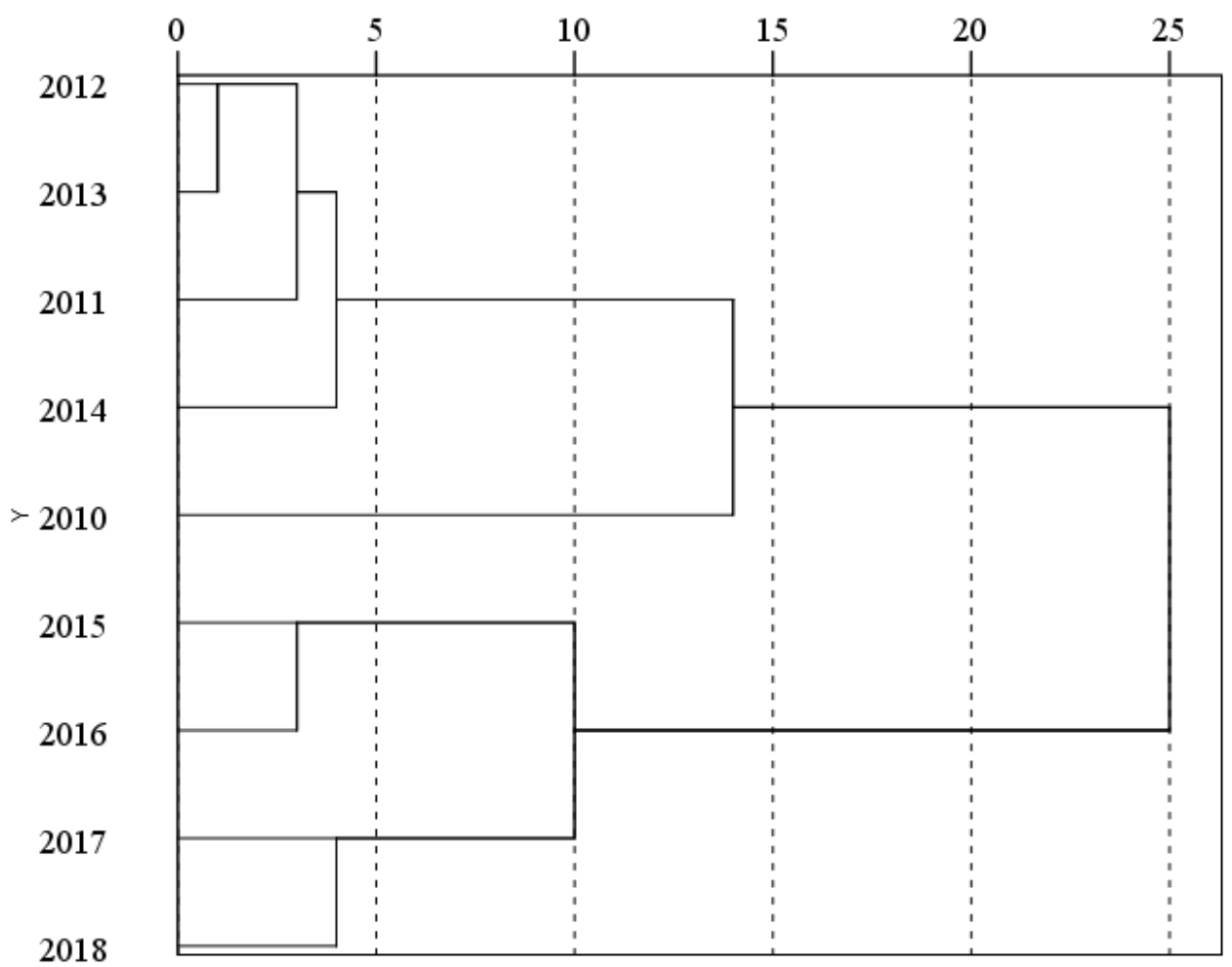

Fig. 3. Dendrogram using the Ward's method

Note: own research

The first cluster includes the observations of 2010, the second - 2011, 2012 and 2013, the third -
2014, the fourth - 2015-2016, the observations of 2017-2018 formed a separate fifth cluster. 


\section{S. Lykholat, Y. Krykavskyi, V. Lozynskiy, N. Shynkarenko}

Cluster models are designed for big, mediumsized, small and microenterprises. The results of cluster analysis are presented only based on data on small enterprises, as the models of the other three groups are similar.

Econometric trend models (polynomial function) of the number of small enterprises and the volume of sales of goods (formula (1)) have been developed. When constructing the model, the values of the correlation coefficients $\left(\mathrm{r}_{\mathrm{xy}}\right)$ and the coefficient of determination $\left(\mathrm{R}^{2}\right)$ formulas (2), (3) were analyzed.

$$
\begin{aligned}
& Y=a_{0}+a_{1} x_{1}+a_{2} x^{2}+\ldots+a_{n} x^{n}+u, \\
& \mathrm{r}_{\mathrm{xy}}=\frac{\frac{1}{\mathrm{n}} \sum\left(\mathrm{x}_{\mathrm{i}}-\overline{\mathrm{x}}\right)\left(\mathrm{y}_{\mathrm{i}}-\overline{\mathrm{y}}\right)}{\sqrt{\frac{\sum\left(\mathrm{x}_{\mathrm{i}}-\overline{\mathrm{x}}\right)^{2}}{\mathrm{n}}} \sqrt{\frac{\sum\left(\mathrm{y}_{\mathrm{i}}-\overline{\mathrm{y}}\right)^{2}}{\mathrm{n}}}}= \\
& =\frac{\sum\left(\mathrm{x}_{\mathrm{i}}-\overline{\mathrm{x}}\right)\left(\mathrm{y}_{\mathrm{i}}-\overline{\mathrm{y}}\right)}{\sqrt{\sum\left(\mathrm{x}_{\mathrm{i}}-\overline{\mathrm{x}}\right)^{2} \sum\left(\mathrm{y}_{\mathrm{i}}-\overline{\mathrm{y}}\right)^{2}}},
\end{aligned}
$$

$$
R^{2}=\frac{\sum\left(\hat{y}_{i}-\bar{y}\right)^{2}}{\sum\left(y_{i}-\bar{y}\right)^{2}} .
$$

Peculiarities of the economic cycle of 20102018 in terms of business implementation could cause such following negative phenomena in the socio-economic development of Ukraine. Such processes are emigration, increase of the shadow sector of the economy, the growth of social benefits, reduction of the share of consumer loans, which led to accumulation of inventories in supply chains (Fig. 4).

The polynomial function of the fourth and second degree describes the trend in the number of enterprises and the volume of sold products, respectively. The high values of the coefficients of determination of 0.9796 and 0.9914 indicate a significant determination of the variation of the dependent variable from the variation of the independent ones.

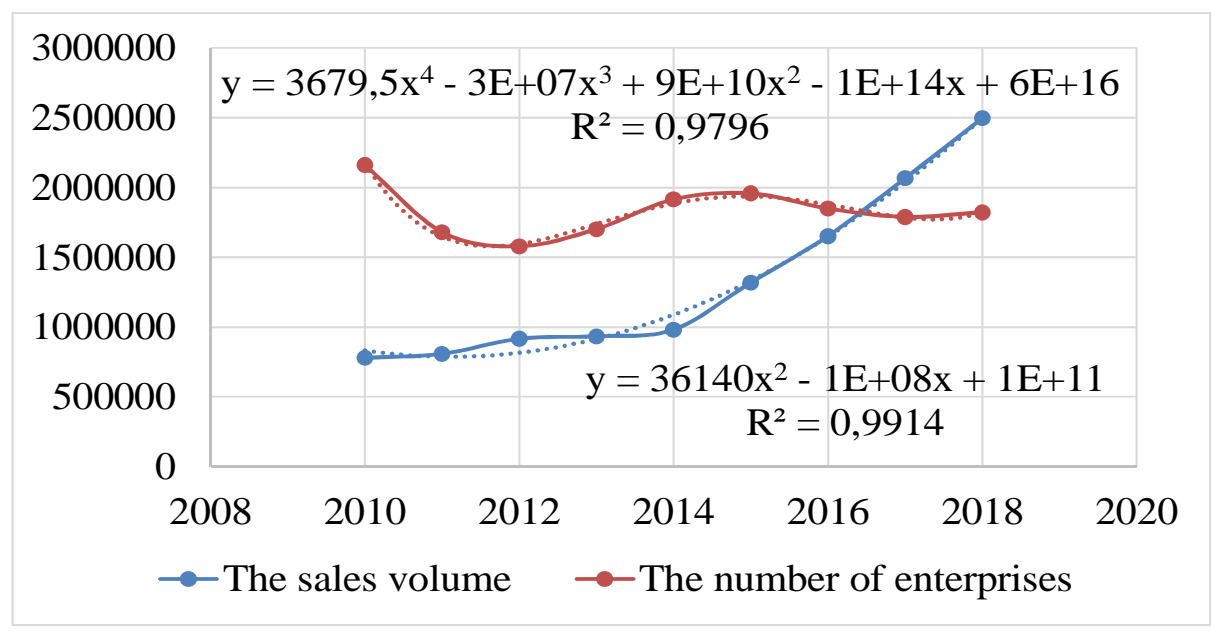

Fig. 4. Comparison of the dynamics

of macroeconomic indicators of small enterprises

Note: own research based on the materials of the State Statistics Service of Ukraine

The subject of system analysis is a variety of characteristics of the system, such as composition, structure, organization, operation and development of the system. Instead, the study of the system position in the environment has a significant interest in terms of determining the economic cycle (in our case, the subsystems of small business among other components of the business system). The basis for effective transformations and / or improvements in accordance with the phases of the economic cycle is ensuring the stabilization, balance of the business system. Creating a flexible interaction of the small business subsystem and the environment, which will better adapt to market changes.

To determine the relationship between the development of different types of businesses, we calculated the correlation coefficients formula (1) (Table 3). 
Determination of the influence of the economic cycle stages...

Table 3

Correlation coefficients between small and other enterprises

\begin{tabular}{|l|c|c|}
\hline \multicolumn{1}{|c|}{ Indicator } & Big entities & Medium-sized entities \\
\hline № 1. Number of business entities & -0.444008665 & -0.14987056 \\
\hline Chain indices of the indicator No. 1 & -0.82538211 & -0.759233828 \\
\hline № 2. Number of employees & 0.790719586 & 0.929220324 \\
\hline Chain indices of the indicator No.2 & -0.029185047 & 0.48682695 \\
\hline № 3. Staff costs & 0.967490965 & 0.966085817 \\
\hline Chain indices of the indicator №. 3 & 0.980101181 & 0.993622089 \\
\hline № 4. Volume of sold products & 0.976959972 & 0.994816109 \\
\hline Chain indices of the indicator No. 4 & 0.449585043 & 0.873060997 \\
\hline № 5. The level of profitability of operating activities & 0.928826227 & 0.861177773 \\
\hline
\end{tabular}

Note: own calculations

Interpretation of these indicators suggests the existence of disparities in the development of entities of small, and big and medium-sized businesses. The disproportion appears in as a strong inverse relationship between the growth rate of the number of enterprises. And, conversely, direct in terms of personnel costs and sales. The reasons for this phenomenon may be the difficulty in obtaining permits and approvals, the weak level of protection of property rights and a significant tax burden for small businesses.

Potential sources of innovation in the small business sector can be information technology and the development of strengths, especially in times of economic growth (will be a factor in safeguarding the negative effects of the economic downturn). In the process of implementing an information system, the company must not only get a corporate system (ERP, MRP), but also have professionally trained employees who are able to use it independently. The introduction of ERP-system is always accompanied by a certain optimization of both the organizational and staffing structure of the enterprise and the processes of its activities. The main criterion for the need of changes should be considered their feasibility in terms of ensuring the effectiveness of the management process of the enterprise as a whole.

In the market of management information systems there is a significant offer of software such as SaaS (software as a service) (USA) for small businesses, which is implemented in a cloud environment. When using such a model, the service and the interface (intended for the user or the program) are obtained without reference to the method of its implementation. The use of such types of RM-systems is widespread in Ukraine as CRM (customer relationship management) and HRM (human resource management). The supply function for small businesses has not yet become strategic in business, so far there is a demand for SRM-systems only from big entities. In developed countries, such as the USA, Germany, Great Britain, such technology transfer has already taken place (if we talk only about RM-systems): large ones used CRM, small ones did not use complex MIS (management information systems) due to high cost, inability to apply or lack of such need. Technological change is related not only to the specialized technology sector. It is related to all economic entities and requires not only private investment, but also public [35]. The next stage was the emergence of a proposal for customer interaction systems for the small business sector using the cloud environment, and the trend in the information technology market was the using of big entities SRM-systems (USA). The third stage (but not the last one) is the possibility of using SRM by small businesses (affordability is evidenced by the cost of using, such as the cost of using one module, such as sales, purchases, of Odoo Enterprise is 6 euros per month). In this case, it is necessary to mention the technological convergence, which requires constant monitoring and spatial measurement of applied innovation processes [36]. 


\section{S. Lykholat, Y. Krykavskyi, V. Lozynskiy, N. Shynkarenko}

The using of information technology can be fragmentary (one or more functions) and systemic. Fig. 5 shows the ratio of the number of companies that have websites with a certain set of functions for working with customers on the one hand and companies that have implemented and those, which use a customer relationship management system on the other hand.

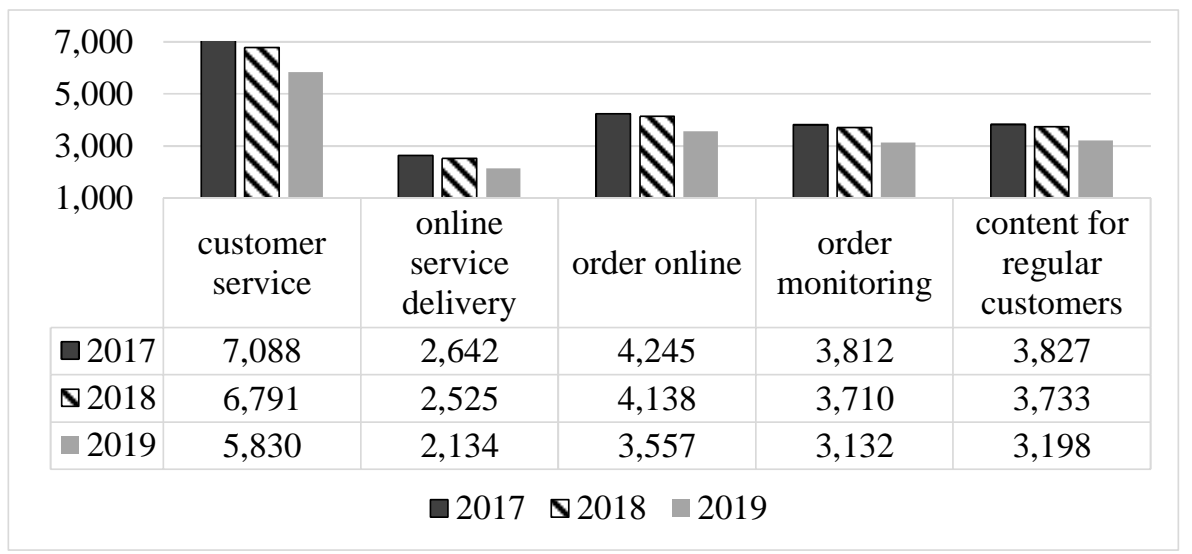

Fig. 5. The ratio of the number of companies that use the website to work with customers to the number of those who use the CRM-system

Note: own research based on the materials of the State Statistics Service of Ukraine

The positive changes in technology transfer are the reduction in the number of entities that use customer service functions separately, manage orders through their own sites, rather than those that implement information systems to work with customers. That is, the number of business entities implementing the management system, rather than its individual elements, is growing. This testifies to the significant innovative potential of small business, as each company tries every year to approach more and more comprehensively and systematically to the management of their business processes, in this case to the organization of work with clients.

During 2013-2019 (except 2015) value added by production costs as a percentage of the total number of different types of enterprises of small and micro enterprises increases. The trend may indicate a decrease in the efficiency of cost management, as well as increasing the role of such entities in the supply chain [28].

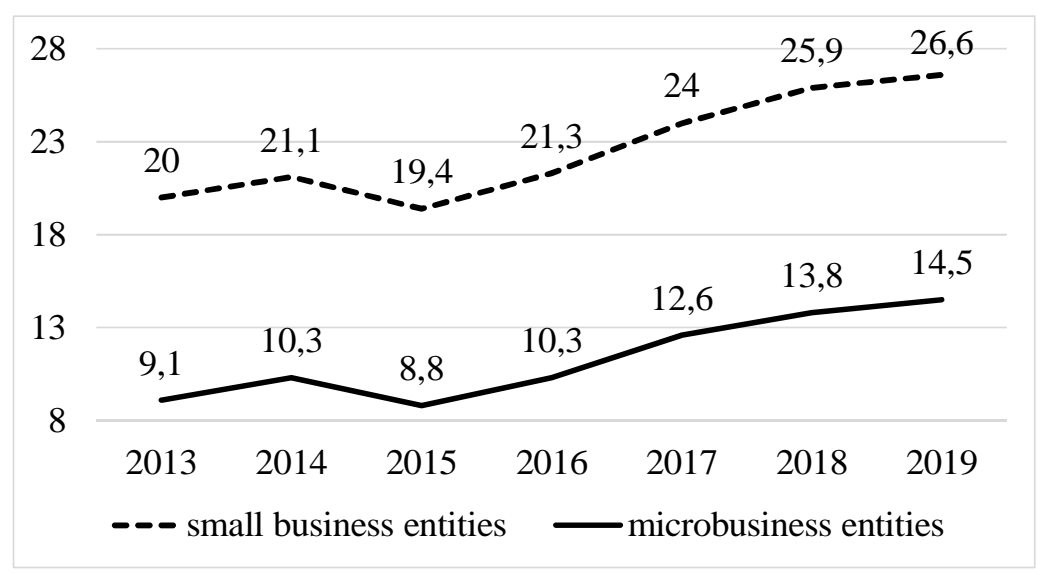

Fig. 6. Value added at production costs to the total of all types of enterprises, $\%$

Note: own research based on the materials of the State Statistics Service of Ukraine

The dynamics of socio-economic development of the small business sector of the economy, the growth of its weight in supply chains, the use of information systems in economic activity - these 
are signs that may indicate a susceptibility to the transfer of digital technologies of this type of enterprise.

One of the areas of state balancing stagnation and innovation opportunities is to simplify and expand access to management information systems. For the small business sector that is ERP (enterprise resource planning), modules for marketing: CRM (customer relationship management), PLM (product lifecycle management), SPM (sales performance management). Modules for logistics are SRM (supplier relationship management), WMS (warehouse management system), TMS (transport management system), SCM (supply chain management), FRP (financial resource planning). Except for the first, all others can be both separate information systems and ERP-system modules.

Limited access to financial resources, high vulnerability to adverse economic factors such as inflation, tax pressure, political cyclicality, etc., big business pressure, administrative barriers, lack of effective state support affect the low activity of small business and its instability. The hypothesis of the existence of a medium-term economic cycle of small business is confirmed by the results of cluster analysis using two variables (number of employees and sales). Another result of such a research is the possibility of applying the hierarchical Ward's clustering method with the calculation of the Chebyshev distance to identify stages of small business development.

After analyzing the level of profitability of economic entities operating activities and the level of profitability of economic activity, the existence of an economic cycle was established. As practice has shown, there is a high probability that the phases of the economic cycle of small business are synchronous with the phases of the national economy and create a basis for the development of strategies that take into account asynchronous phenomena. That is, small businesses are interested in acting responsibly and promoting a progressive environment. The calculation of the chain index of some indicators of economic entities showed that in the period 2010-2018, small businesses were created without the involvement of employees.

Thus, we can conclude that there is a somewhat paradoxical relationship: in a period of economic downturn, the attractiveness and need for innovation increases, and investment opportunities decrease, in a period of growth - vice versa. Given this, the role of the state is important for balancing economic development and investment in innovation.

Such conclusions can be considered appropriate from a practical point of view, because they allow a reasonable approach to the formation of state policy on socio-economic development of the small business sector. From a theoretical point of view, the obtained conclusions allow us to aver the possibility of identifying the stages of the economic cycle through the using of cluster analysis in combination with the index method. However, it should be noted that the results of determining the stages of the cycle indicate the ambiguous impact of technology transfer of economic entities in different sectors of the economy. Such uncertainty imposes certain restrictions on the using of the obtained results, which can be interpreted as shortcomings of this research. The inability to remove such restrictions in this research raises a potentially interesting area for further research. Future research may focus on identifying the readiness of small businesses to innovate and on the appropriate actions of public authorities to support such a process.

\section{Conclusions}

1. The small business sector is an important part of the socio-economic system of Ukraine as due to its own flexibility it is able to respond to changes quickly in the external environment. Creation of sufficient number of jobs deals with the negative effects of structural and frictional unemployment. Indicators of increasing the use of information systems indicate significant innovation potential of small business, rather than their separate functions (Pic. 5) and the growth of value added in the supply chain (Pic. 6).

2. Investing innovations in the small business sector significantly depends on the cycle: during the downturn, business opportunities reduce, so the influence of the state should increase through budget incentives, budget financing, at the stage of growth on the contrary - a growing source of financing innovation in small business from big business. Based on the obtained information, an econometric 


\section{S. Lykholat, Y. Krykavskyi, V. Lozynskiy, N. Shynkarenko}

trend model (polynomial function) was developed, due to which the values of the correlation coefficient $\left(\mathrm{r}_{\mathrm{xy}}\right)$ and the determination coefficient $\left(\mathrm{R}^{2}\right)$ were analyzed. Interpretation of the obtained calculations indicates a disproportion in the development of small business compared to big and medium-sized ones. Such data testifies to the unsystematic development of small business and its non-priority in the state policy of the country.

3 . The structure / directions of investment innovations in the small business sector are determined by the global market situation: in the period of economic growth, the emphasis is on sales, thus the stimulation of technological innovation decreases, in the period of economic downturn, stagnation - the emphasis shifts to cost-, material-, energy-saving innovations, which leads to interest in technology transfer.

The identification of the economic cycle and the research of the balance in small business subsystem of the whole business system allowed forming the directions of state regulation and deregulation in this area by:

- creation of favourable conditions for attracting labour in the industry, which should be "grown" (information technology, agriculture, gasextraction, transport);

- implementation of the state program of cluster policy in Ukraine;

- information (methodological, consulting), financial (although a system of incentives, rather than direct funding should be the priority) assistance and the formation of tax instruments to assist in the formation of clusters, both intra-regional and regional;

- lending to small businesses to take educational express courses in the direction of implementing innovative approaches to business development and using in practice of management information systems. Higher education institutions would provide such courses.

Further research is planned to model a possible scenario for improving the situation of the small business subsystem as a factor in improving the balance level of the domestic business system using innovative approaches and modern technologies.

\section{References}

1. Constantinescu-Băeșu, C. (2005). Studiul managementului firmei în condițiile ciclicității din viața economică. Lasi: Sedcom Libris Publishing House.

2. Negucioiu, A. (1998). Economie Politic, Vol.1 si 2, editura George Bariiu, ClujNapoca. 208 p.

3. Ritonga, W. (2018). How to Enhance Society's Income through Entrepreneurship, Information and Legislation Policy. European Research Studies Journal, Volume XXI, Issue 4, 459-469. EOI: 10.11214/thalassinos.21.04.036. Available at: https://www.ersj.eu/dmdocuments/2018_XXI_4_36. $p d f$

4. Hustan T., Lykholat S., Veresklya M., Mykhalitska N., Taranskyi I. (2020). Standardization, specialization and formatization as the factors of retail trade competitiveness. Financial and credit activity: problems of the theory and practice, 34(3), 432440. Available at: https://fkd.ubs.edu.ua/index.php/ fkd/article/view/2926/3057

5. Kozubiková, L., Belás, J., Bilan, Y., \& Bartoš, P. (2015). Personal Characteristics of Entrepreneurs in the Context of Perception and Management of Business Risk in the SME Segment. Economics and Sociology, 8(1). DOI: http://dx.doi.org/10.14254/ 2071-789X.2015/8-1/4 Available at: https://www. researchgate.net/publication/281547973_Personal _characteristics_of_entrepreneurs_in_the_context _of_perception_and_management_of_business_ris $k$ in_the_SME_segment

6. Břčková, P., Havlíček, K. (2013). Leaders Management and Personnel Controlling in SMEs. European Research Studies Journal, Volume XVI, Issue 4, 3-14. EOI: 10.11214/thalassinos.16.04.001 Available at: https://www.ersj.eu/repec/ers/papers/ 13_4_pl.pdf

7. Havliček, K., Schlossberger, O. (2013). New Trends of Management of European SMEs: The MC Model. European Research Studies Journal, Volume XVI, Issue 4, 43-56, 2013. EOI: 10.11214/thalassinos.16.04.004 Available at: https://www.ersj.eu/repec/ers/papers/13_4_p4.pdf

8. Meutia Tubagus Ismail, Ahmad Bukhori (2017). The Role of Feedback and Feed Forward Control System to Improve Competitive Advantage of SMEs in Indonesia. European Research Studies Journal, Volume XX, Issue 2A, 496-506, 2017. EOI: 10.11214/thalassinos.20.02.030 Available at: https://www.ersj.eu/repec/ers/papers/17_2_A_p30. $p d f$

9. Lee, V. H., Foo, A. T., Lai-Ying, L. Y., KengBoon, K. B. (2016). Can competitive advantage be achieved through knowledge management? A case 
Determination of the influence of the economic cycle stages...

study on SMEs. Expert Systems with Applications, 65 (1), 136-151.

10. Varnalii Z. S. , Kampo V. (2005). M. Political and legal regulation of entrepreneurship in Ukraine: theory and practice: a monograph. Kyiv: Znannia Ukraiiny. 324 p.

11. Downs, Anthony. An Economic (1957). Theory of Political Action in a Democracy. Journal of Political Economy, vol. 65, no. 2, p. 135-150. Available at: https://www.jstor.org/stable/ 1827369? refreqid=excelsior\%3A1905622c787e42c7b3508234 $27 f d 7 d 84 \&$ seq $=1$

12. Pokryshka D. S., Zhalilo Ya. A., Liapin D. V., Belinska Ya. V. and others (2010). Mechanisms of business development in the conditions of postcrisis recovery of Ukraine's economy. Kyiv: NISD. 72 p. (Analytical report).

13. Belás, J., Bartoš, P., Habánik, J., \& Novák, P. (2014). Significant Attributes of the Business Environment in Small and Meduim-Sized Enterprises. Economics and Sociology, 7(3). DOI: http://dx.doi. org/10.14254/2071-789X.2014/7-3/2 Available at: https://www.economics-sociology.eu/files/ 06_48_Belas_Bartos_Habanik_Novak.pdf

14. Pisar, P., \& Bilkova, D. (2019). Controlling as a tool for SME management with an emphasis on innovations in the context of Industry 4.0. Equilibrium. Quarterly Journal of Economics and Economic Policy, 14(4), 763-785. https://doi.org/ 10.24136/eq.2019.035 Available at: http://economicresearch.pl/Journals/index.php/eq/article/view/ 1751

15. Eric Heyer (2011). The effectiveness of economic policy and position in the cycle: The case of tax reductions on overtime in France. HAL Id: hal01069482 https://hal-sciencespo.archives-ouvertes.fr/ hal-01069482 Available at: https://hal-sciencespo. archives-ouvertes.fr/hal-01069482

16. Krajnakova, E., Navickas, V., \& Kontautiene, R. (2018). Effect of macroeconomic business environment on the development of corporate social responsibility in Baltic Countries and Slovakia. Oeconomia Copernicana, 9(3), 477-492. https://doi.org/10.24136/oc.2018.024 Available at: http://economic-research.pl/Journals/index.php/ oc/article/view

17. Zygmunt, J. (2018). Entrepreneurial activity drivers in the transition economies. Evidence from the Visegrad countries. Equilibrium. Quarterly Journal of Economics and Economic Policy, 13(1), 89-103. https://doi.org/10.24136/eq.2018.005 Available at: http://economic-research.pl/Journals/ index.php/eq/article/view/726
18. Karpak, B., Topcu, I. (2010), Small medium manufacturing enterprises in Turkey: an analytic network process framework for prioritizing factors affecting success, International Journal of Production Economics, 125, p. 60-70. Available at: https://www.sciencedirect.com/science/article/ abs/pii/S0925527310000113

19. Henderson, J., Weiler, S. (2010), Entrepreneurs and job growth: probing the boundaries of time and space, Economic Development Quarterly, 24(1), p. 23-32. Available at: https://journals. sagepub.com/doi/pdf/10.1177/0891242409350917

20. Sumiati, Ainur Rofiq, Sigit Pramono (2019). The Role of Strategic Planning and Flexibility in Shaping SMEs Market Orientation in Turbulence Business Environment. European Research Studies Journal, Volume XXII, Issue 1, 221-236, 2019. EOI: 10.11214/thalassinos.22.01.015 Available at: file:///C:/Users/hp/Downloads/The\%20Role\%20of $\% 20$ Strategic\%20Planning\%20and\%20Flexibility \%20in\%20Shaping\%20SMEs\%20Market\%20Orie ntation\%20in\%20Turbulence\%20Business\%20Env ironment.pdf

21. Behr, P., \& Guettler, A. (2007). Credit Risk Assess ment and Relationship Lending: An Empirical Analysis of German Small and Medium-Sized Enterprises. Journal of Small Business Management, 45(2). DOI: http://dx.doi.org/ 10.1111/j.1540-627X.2007.00209.x Available at: https://onlinelibrary.wiley.com/doi/abs/10.1111/j.1 540-627X.2007.00209.x

22. Cipovova, E., \& Dlaskova, G. (2016). Comparison of Different Methods of Credit Risk Management of the Commercial Bank to Accelerate Lending Activities for SME Segment. European Research Studies Journal, Volume XIX, Issue 4, 17-26, 2016. EOI: 10.11214/thalassinos.19.05.002 Available at: https://www.ersj.eu/repec/ers/papers/16_4_p2.pdf

23. Jindrichovska, I. (2013). Financial Management in SMEs. European Research Studies Journal, Volume XVI, Issue 4, 79-96, 2013. EOI: 10.11214/thalassinos.16.04.007 Available at: https://www.ersj.eu/repec/ers/papers/13_4_p7.pdf

24. Havlíček, K., Thalassinos, E., Berezkinova, L. (2013). Innovation Management and Controlling in SMEs. European Research Studies Journal, Volume XVI, Issue 4, 57-70, 2013. EOI: 10.11214/thalassinos.16.04.005 Available at: https://www.ersj.eu/repec/ers/papers/13_4_p5.pdf

25. Janssen, C., Sen, S., \& Bhattacharya, C. B. (2015). Corporate crises in the age of corporate social responsibility. Business Horizons, 58. doi: 10.1016/j.bushor.2014.11.002 Available at: 


\section{S. Lykholat, Y. Krykavskyi, V. Lozynskiy, N. Shynkarenko}

https://www.sciencedirect.com/science/article/abs/ pii/S0007681314001578

26. Przybylska A (2005). Innowacje w przedsiębiorstwie skuteczność a wymiar społeczny. Prace Naukowe Instytutu Organizacji i Zarzadzania Politechniki Wrocławskiej. Studia i Materiały. vol. 18. Issue $n r$ 76, t. 2, 51-61. Available at: http://yadda.icm. edu.pl/yadda/element/bwmetal.element.ekonelement-000171226823?q=60db8b21-4c08-43969093-82ae2e58a24e\$2\&qt=IN_PAGE

27. Osuch-Rak E (2017). Transfer technologii w Polsce na przykładzie spółek odpryskowych wywodzacych się $z$ instytutów badawczych $i$ naukowych. Kwartalnik Kolegium EkonomicznoSpotecznego Studia i Prace / Szkoła Główna Handlowa. Issue nr 3, 131-149. Available at: https://econjournals.sgh.waw.pl/kwes/article/view/ $42 / 35$

28. Krykavskyy, Y., Pokhylchenko, O., \& Hayvanovych, N. (2019). Supply chain development drivers in industry 4.0 in Ukrainian enterprises. Oeconomia Copernicana, 10(2), 273-290. doi: 10.24136/oc.2019.014 Available at: 1571ArticleText-1495-1-10-20190709 (1).pdf

29. Schumpeter Josef A. (2014) Theory of Economic Development: A Study of Profit, Capital, Credit, Interest, and the Economic Cycle. K .: Publishing House "Kyiv-Mohyla Academy”. P. 205-243.

30. Menshikov SM (1989). Long waves in the economy. When society changes its skin. M .: International relations. S. 182.

31. Perez K. (2011). Technological revolutions and financial capital. Dynamics of bubbles and periods of prosperity. Moscow: Delo Publishing House, Russian Academy of Natural Sciences and Geography. Pp. 76-86.

32. Snyder M. (2014) Economic Cycle Theorists Are Correct, 2015 To 2020 Will Be Pure Hell For The United States / Michael Snyder// MND. Available at: http://michaelsnyder.mensnewsdaily.com/2014/ 05/ifeconomic-cycle-theorists-are-correct-2015-to2020-will-be-pure-hell-for-the-united-states/

33. Doing business-2019. Україна в рейтингу світового банку легкості ведення бізнесу. Економічний дискусійний клуб Available at: https://www.doingbusiness.org/content/dam/doing Business/country/u/ukraine/UKR.pdf

34. Andersson T., Schwaag-Serger S., Sörvik J., Hansson E. (2004). The Cluster Policies Whitebook / IKED. Available at: https://www. researchgate.net/publication/284163165_The_Clus ter_Policies_Whitebook

35. Kotlebova, J., Arendas, P., \& Chovancova, B. (2020). Government expenditures in the support of technological innovations and impact on stock market and real economy: the empirical evidence from the US and Germany. Equilibrium. Quarterly Journal of Economics and Economic Policy, 15(4), 717-734. https://doi.org/10.24136/eq.2020.031 Available at: http://economic-research.pl/Journals/ index.php/eq/article/view/1840/1719

36. Kijek, A., \& Matras-Bolibok, A. (2020). Technological convergence across European regions. Equilibrium. Quarterly Journal of Economics and Economic Policy, 15(2), 295-313. https://doi.org/10.24136/eq.2020.014 Available at: http://economic-research.pl/Journals/index.php/eq /article/view/1795 